\title{
Anthelminthic effects of extracts of indigenous browses from mid rift valley of Ethiopia
}

\author{
Amsalu Sisay*, Tegene Negesse, and Ajebu Nurfeta \\ School of Animal and Range Sciences, College of Agriculture, Hawassa University, Ethiopia \\ *Correspondence author:_solianaa2008@gmail.com or amsals2001@yahoo.com
}

\begin{abstract}
This study was conducted to evaluate the potential anthelminthic properties of extracts of leaves of indigenous browses (Acacia seyal, Acacia senegal, Acacia tortilis, Millettia ferruginea, and Vernonia amygadalina) based on three in vitro assays. Acetone extracts of browses at different concentrations (75 to $1200 \mu \mathrm{g} / \mathrm{ml}$, for egg and larvae and $100 \mathrm{mg} / \mathrm{ml}$ for an adult) were tested on three developmental stages of Haemonchus contortus (eggs, infective larvae, and adult worms) using egg hatch assay (EHA), larval migration inhibition assay (LMIA) and adult worm motility inhibition assay (AMIA). Significant effects were obtained with all five browses but differences were observed depending on the parasitic stages. The effects of five browse extracts on egg hatching were concentration-dependent, the highest $(P<0.05)$ egg hatch inhibition rate was observed at $1200 \mu \mathrm{g} / \mathrm{ml}$ concentration for all browses. All extracts had a higher effect $(P<0.01)$ than that of the negative control, phosphate buffer saline (PBS). In contrast, no concentration-response relationship was found for infective larvae and adult worms, although more potent effects were observed with the highest concentrations. The LMI rate (70\%) induced by Vernonia amygadalina extract, at a concentration of $300 \mu \mathrm{g} / \mathrm{ml}$, was the highest $(P<0.05)$ of all other browses, even at higher concentrations. The highest LMI rate $(62 \%)$ induced by Acacia senegal extract at higher concentration, was lower than that of LMI rate $(70 \%)$ induced by Vernonia amygadalina, at $300 \mu \mathrm{g} / \mathrm{ml}$ concentration. Vernonia amygadalina was found to be highly and rapidly effective against adult worms inducing the highest mortality rate (90\%) as soon as $4 \mathrm{hrs}$ after incubation. Overall, the in vitro results suggest that these five browses do possess anti-parasitic properties and Vernonia amygadalina showed the most effective anti-parasitic property. These effects remain to be confirmed through in vivo study.
\end{abstract}

Keywords: Haemonchus contortus; Acacia seyal; Acacia senegal; Acacia tortilis; Millettia ferruginea; Vernonia amygadalina; in vitro method; anti-parasitic. 


\section{Introduction}

Helminthosis is one of the major problems of livestock production throughout the world, particularly in tropical and subtropical areas. In tropical and subtropical regions, where the parasites are more abundant due to favorable environmental conditions, helminthosis is even more devastating (Pathak 2013). Moreover, extensive grazing on native pastures, together with a lack of supplemental nutrients to animals in these areas leads to a low plane of nutrition and, therefore, increased susceptibility. The gastrointestinal parasite has resulted in up to $40 \%$ reduction in live weight gain and a $6-30 \%$ reduction in feed intake by lambs (Pathak, 2011).

Haemonchus contortus is a blood-sucking nematode parasite. Both the larvae (L4) and the adults of Haemonchus species suck blood (Qamar and Maqbool, 2012), primarily occurring in the abomasum of small ruminants, notably sheep and goats. The parasites cause retarded growth, loss of appetite, anemia, edema, decrease in protein, and even mortality in young animals (Qamar and Maqbool, 2012).

The increasing prevalence of anthelmintic resistance in nematodes in domestic ruminants, combined with rising consumer concerns about chemical use on farms, has encouraged research into alternative strategies for the control of internal parasites (Niezen et al., 1993). Apart from anthelmintic resistance, poor availability and affordability of anthelmintics to small-scale farmers in developing countries have compounded the problem (Hammond et al., 1997). It follows that a search for novel and more sustainable anthelmintics is the best approach to the control of helminthosis.

The vast majority of the in-vivo and in-vitro studies examining the effects of browses against the gastrointestinal nematodes have been performed on temperate legume forages (Hoste et al., 2009). Although indigenous browses are largely distributed in the tropics, especially in East Africa, only a limited number of in vitro studies have addressed the question of their potential anthelmintic properties (Papachristou et al., 2005). Particularly, indigenous browses from the Rift Valley of Ethiopia are not studied for their potentials to control gastrointestinal parasites (GIP) in the ruminants. The current study was therefore conducted to explore the potential anti-parasitic properties of five indigenous browses from the Rift Valley of Ethiopia against H. contortus. In 
vitro methods were employed targeting three life-cycle stages of $H$. contortus, i.e., the eggs, the infective larvae, and the adult worms.

\section{Materials and methods}

\section{Extract preparation}

Leaf samples of experimental browses were collected from the Mid Rift Valley of Ethiopia at the end of the main rainy season (September 2017). The harvested fresh samples were shed dried and then oven-dried at $60^{\circ} \mathrm{C}$ for $48 \mathrm{~h}$ and ground using $1.0 \mathrm{~mm}$ sieve size for extraction. Plant leaf extracts were prepared using the method of Makkar (2003). Accordingly, $5 \mathrm{~g}$ of ground plant material were taken in a glass beaker of $125 \mathrm{ml}$ capacity. Then $100 \mathrm{ml}$ of aqueous acetone $(70 \%)$ was added and the beakers were suspended in an ultrasonic water bath and subjected to ultrasonic treatment for 20 minutes at room temperature (20 $\left.{ }^{\circ} \mathrm{C}\right)$. The contents of the beakers were then transferred to centrifuge tubes and subjected to centrifugation for 10 minutes at approximately $3000 \mathrm{~g}$ at $4{ }^{\circ} \mathrm{C}$. The supernatant was collected and concentrated in a rotary evaporator at $40{ }^{\circ} \mathrm{C}$ under reduced pressure. Thereafter, the concentrated filtrate was freeze-dried to obtain a grounded sample. To prepare the extract solutions applied in the bioassays, the powders were dissolved in phosphate buffer saline (PBS 0.1M, $\mathrm{pH} 7.2$ ) to make the following different concentrations: 75, 300, and $1200 \mu \mathrm{g} / \mathrm{ml}$ for $\mathrm{EH}$ test; 150, 300, and $600 \mu \mathrm{g} / \mathrm{ml}$ for LMI test; and $100 \mathrm{mg} / \mathrm{ml}$ for AMI test.

\section{Egg hatch assay (EHA)}

This test was performed according to the procedure described by Coles et al. (2006). Briefly, parasite eggs were freshly obtained from donor goats experimentally infected with $H$. contortus. The eggs were extracted by simple flotation method, washed repeatedly with saline, and distributed on 24 multi-well plates at a concentration of 100 eggs/well in $200 \mu \mathrm{l}$. For the treatment, $1 \mathrm{ml}$ of plant extract prepared with PBS at different concentrations (75, 300, and 1200 $\mu \mathrm{g} / \mathrm{ml}$ ) were added to well plates containing eggs. An oxfendazole at concentrations of $10 \mu \mathrm{g} / \mathrm{ml}$ was used as positive control and an egg with PBS was used as a negative control. Each concentration was tested in triplicates.

The eggs were incubated for $48 \mathrm{hr}$ at $24{ }^{\circ} \mathrm{C}$. Thereafter, the number of larvae present per well was counted under the microscope and the hatching percentage was determined as the ratio between the number of larvae to the number 
of eggs deposited per well. A mean value was calculated for each concentration of the different plants.

\section{Larval migration inhibition assay (LMIA)}

\section{Collection of larvae}

Infective larvae of $H$. contortus (L3) were obtained by fecal culture of eggs collected from an experimentally infected goat. After egg hatching, the infective stage was reached after 10 days. The L3 were then collected by sedimentation using Baermann's apparatus.

The larval migration inhibition (LMI) bioassay was used as described by Rabel et al. (1994) to measure inhibiting activity against infective larvae (L3). Briefly, larvae were incubated for $3 \mathrm{~h}$ at $20{ }^{\circ} \mathrm{C}$ in phosphate buffer solutions (PBS) of plant extracts, at concentrations of 150,300 , or $600 \mu \mathrm{g} / \mathrm{ml}$. The larvae were then washed three times in PBS and centrifuged. After the last washing, 500 $\mu \mathrm{l}$ of larvae at a concentration of $1000 \mathrm{~L} 3 / \mathrm{ml}$ was pipetted onto a $20 \mu \mathrm{m}$ mesh. The sieve was inserted into a conical tube so that it just touched the surface of the PBS contained therein. Three replicates were run at room temperature for each plant concentration. In addition, negative control (larvae incubated in PBS) and positive control (larvae incubated in levamisole at a concentration of $500 \mu \mathrm{g} / \mathrm{ml}$ ) were run in parallel. After $3 \mathrm{~h}$, the L3 above the sieve were discarded and those which had actively migrated through the mesh into the PBS below were counted under the Microscope.

The percentage of LMI was calculated as $=(\mathrm{T}-\mathrm{M} / \mathrm{T})^{*} 100$; where $\mathrm{T}$ is the total number of L3 deposited in the sieve and $\mathrm{M}$ is the number of L3 having migrated through the mesh into the PBS.

\section{Adult worm motility inhibition assay (AMIA)}

The adult motility inhibition (AMI) bioassay was used as described by Tariq et al. (2009). The adult worms were collected from the abomasa of freshly slaughtered goats, washed, and finally suspended in PBS. The 20-25 adult, actively moving $H$. contortus worms were exposed in triplicate in each Petridish containing $100 \mathrm{mg} / \mathrm{ml}$ concentration of the plant extract prepared in $5 \mathrm{ml}$ of PBS and PBS alone for the negative control groups. Levamisole at the rate of $0.5 \mathrm{mg} / \mathrm{ml}$ was used as a reference drug of positive control. The Petri dishes were kept in an incubator at $37^{\circ} \mathrm{C}$ for 8-hrs. The inhibition of motility, active- 
ness, and mortality of the worms was observed at an interval of $0.5,1,2,4,6$, $8 \mathrm{~h}$. The number of motile (alive) and nonmotile (dead) worms were counted under the stereomicroscope and recorded for each concentration. The death of worms was ascertained by the absence of motility for an observation period of 30 seconds in the lukewarm fresh PBS.

\section{Statistical analysis}

Data were analyzed using the general linear model (GLM) procedure of SAS, Version 9.2. The effects of browse extract, concentration, and the interaction effects on EHI, LMI, and AMI were analyzed by two-factor ANOVA with the following model; $\mathrm{Y}_{\mathrm{ij}}=\mu+\mathrm{B}_{\mathrm{i}}+\mathrm{C}_{\mathrm{j}}+\mathrm{B} * \mathrm{C}_{\mathrm{ij}}+\mathrm{e}_{\mathrm{ij}}$. Where: $\mathrm{Y}_{\mathrm{ij}}$ is an observation, $\mu$ is the overall mean, $B_{i}$ is the effect of browse extracts, $C_{j}$ is the effect of concentration, $\mathrm{B}^{*} \mathrm{C}_{\mathrm{ij}}$ is the interaction between browse species and concentration, and $e_{i j}$ is the experimental error. All laboratory analyses of each browse extracts were conducted in triplicates. The means were separated by Duncan multiple range test. Differences between means were considered statistically significant if $P<0.05$.

\section{Results}

\section{Egg hatch inhibition assay}

The percentage of inhibition of egg hatching at different concentrations of plant extracts and their overall means are indicated in Table 1. More than 90\% of eggs in negative control were hatched. Compared to the negative control, all plant extracts showed $(P<0.05)$ higher egg hatching inhibition rates. All extracts inhibited egg hatching in a concentration-dependent manner with a maximum inhibition of $50 \%$ at the highest concentration $(1200 \mu \mathrm{g} / \mathrm{ml})$ for Acacia tortilis and lowest inhibition of $17 \%$ at the lowest concentration $(75 \mu \mathrm{g} / \mathrm{ml})$ for Acacia seyal. Oxfendazole used as positive control significantly $(P<0.001)$ inhibited egg hatching with an inhibition rate of $85 \%$. 
Table 1. Percentage egg hatch inhibition of extracts of five browse leaves from Rift Valley of Ethiopia at different concentrations ( $\mu \mathrm{g} / \mathrm{ml})(2017, \mathrm{G} . \mathrm{C})$

\begin{tabular}{lcccc}
\hline & & Concentration $(\boldsymbol{\mu g} / \mathbf{m l})$ & \\
\cline { 4 - 4 } Plant extract & Overall mean & $\mathbf{7 5}$ & $\mathbf{3 0 0}$ & $\mathbf{1 2 0 0}$ \\
\hline Oxfendazole $(10 \mu \mathrm{g} / \mathrm{ml})$ & $85.00^{\mathrm{a}}$ & - & - & - \\
Millettia ferruginea & $31.67^{\mathrm{b}}$ & $20.00^{\mathrm{B}}$ & $35.00^{\mathrm{A}}$ & $40.00^{\mathrm{A}}$ \\
Acacia senegal & $33.00^{\mathrm{b}}$ & $20.00^{\mathrm{B}}$ & $38.00^{\mathrm{A}}$ & $41.00^{\mathrm{A}}$ \\
Vernonia amygadalina & $35.00^{\mathrm{b}}$ & $23.00^{\mathrm{B}}$ & $40.00^{\mathrm{A}}$ & $42.00^{\mathrm{A}}$ \\
Acacia tortilis & $37.00^{\mathrm{b}}$ & $22.00^{\mathrm{C}}$ & $39.00^{\mathrm{B}}$ & $50.00^{\mathrm{A}}$ \\
Acacia. seyal & $31.00^{\mathrm{b}}$ & $17.00^{\mathrm{B}}$ & $34.00^{\mathrm{A}}$ & $42.00^{\mathrm{A}}$ \\
PBS & $10.00^{\mathrm{c}}$ & - & - & - \\
SE & 2.5 & 3.0 & 3.0 & 3.0 \\
\hline $\begin{array}{l}\text { Means with different superscripts (a, b, c) in the same column and (A, B, C) in the same row differ significantly } \\
\text { P<0.05). PBS = phosphate buffer saline }\end{array}$ & & &
\end{tabular}

\section{Larval migration inhibition assay}

The positive control, levamisole, was effective since the larval migration inhibition (LMI) rate was $85 \%$. The migration rate observed for the larvae of the negative control was $90 \%$ (Table 2). A significant effect of the extracts of the five browse on larval migration $(P<0.01)$ was observed. Overall, the inhibition rates obtained with the Acacia senegal, Acacia tortilis, and Vernonia amygadalina extracts $(P<0.01)$ were highest as compared to other browse extracts. The inhibition rate of Vernonia amygadalina extract was $(P<0.01)$ highest at 300 $\mu \mathrm{g} / \mathrm{ml}$ concentration. The inhibition rate obtained with the Acacia senegal extract $(P<0.01)$ was higher than others except for Acacia tortilis at $150 \mu \mathrm{g} /$ $\mathrm{ml}$ concentration. Although a tendency was observed for the highest effects to be associated with the highest concentrations, whatever the plant, a doseresponse relationship was similar among the plant extracts. 
Table 2. Percentage larval migration inhibition of extracts of five browse leaves Rift Valley of Ethiopia at different concentrations $(\mu \mathrm{g} / \mathrm{ml})(2017$, G.C)

\begin{tabular}{lcccc}
\hline Plant extract/control & Overall mean & \multicolumn{3}{c}{ Concentration $(\boldsymbol{\mu g} / \mathbf{m l})$} \\
\cline { 3 - 5 } & & $\mathbf{1 5 0}$ & $\mathbf{3 0 0}$ & $\mathbf{6 0 0}$ \\
\hline Levamisole $(0.5 \mathrm{mg} / \mathrm{ml})$ & $85.00^{\mathrm{a}}$ & - & - & - \\
Millettia ferruginea & $19.00^{\mathrm{d}}$ & $5.00^{\mathrm{cB}}$ & $2.00^{\mathrm{cB}}$ & $50.00^{\mathrm{bA}}$ \\
Acacia senegal & $55.67^{\mathrm{b}}$ & $45.00^{\mathrm{aB}}$ & $60.00^{\mathrm{abA}}$ & $62.00^{\mathrm{aA}}$ \\
Vernonia amygadalina & $50.00^{\mathrm{bc}}$ & $25.00^{\mathrm{bC}}$ & $70.00^{\mathrm{aA}}$ & $55.00^{\mathrm{abB}}$ \\
Acacia tortilis & $51.33^{\mathrm{bc}}$ & $35.00^{\mathrm{abB}}$ & $62.00^{\mathrm{abA}}$ & $57.00^{\mathrm{abA}}$ \\
Acacia. seyal & $46.33^{\mathrm{c}}$ & $30.00^{\mathrm{bB}}$ & $57.00^{\mathrm{bA}}$ & $52.00^{\mathrm{abA}}$ \\
PBS & $10.00^{\mathrm{e}}$ & - & - & - \\
SEM & 2.5 & 2.6 & 2.6 & 2.6 \\
\hline Means with different superscripts (a, b, c) in the same column and (A, B, C) in the same row differ significantly \\
$(P<0.05)$. PBS = phosphate buffer saline
\end{tabular}

\section{Adult worms' motility inhibition assay}

The efficacy of the five plant extracts on adult $H$. contortus is indicated in Table 3 . The effects of extracts on survival of $H$. contortus were time-dependent and there were differences $(P<0.05)$ among plant extracts in the rate of worm mortality at all times after $2 \mathrm{~h}$ of incubation. All plant extracts except Acacia seyal caused a greater than $70 \%$ mortality rate at $4 \mathrm{~h}$ of the incubation time. The extract from Vernonia amygadalina showed $90 \%$ mortality of the adult $H$. contortus worms at $4 \mathrm{~h}$ of the incubation time and this was the highest $(P<0.05)$ rate of all other plant extracts followed by Millettia ferruginea at this time. The results revealed that parasites were sluggish and movement was little at $4 \mathrm{hr}$ post-incubation for all plant extracts. Extract from Acacia tortilis induced the highest $(P<0.05)$ mortality rate at $2 \mathrm{~h}$ post-incubation. Levamisole at a concentration of $0.5 \mathrm{mg} / \mathrm{ml}$ caused $50 \%$ mortality at $2 \mathrm{~h}$ post-incubation and $100 \%$ mortality at $4 \mathrm{~h}$ post-incubation. The control (PBS) recorded the lowest mortality rate $(1 \%)$. The differences between plant extracts and control were highly significant $(P<0.001)$. Moreover, all extracts except extract of Acacia seyal induced $100 \%$ adult mortality at $8 \mathrm{~h}$ post-incubation. 
Table 3. Percentage of mortality of adult worms of $H$. contortus at different times after incubation with plant extracts at $100 \mathrm{mg} / \mathrm{ml}$ concentration $(2017$, G.C).

\begin{tabular}{|c|c|c|c|c|c|c|}
\hline \multirow[t]{2}{*}{ Plant extract } & \multicolumn{6}{|c|}{ Time (h) } \\
\hline & $0.5 h$ & $1 \mathrm{~h}$ & $2 \mathrm{~h}$ & $4 h$ & $6 \mathrm{~h}$ & $8 \mathrm{~h}$ \\
\hline Acacia tortilis & 0.00 & 0.00 & $25.00^{b}$ & $75.00^{\mathrm{d}}$ & $92.00^{\mathrm{c}}$ & $100^{\mathrm{a}}$ \\
\hline Acacia seyal & 0.00 & 0.00 & $8.00^{\mathrm{e}}$ & $17.00^{\mathrm{e}}$ & $50.00^{\mathrm{e}}$ & $50.0^{\mathrm{b}}$ \\
\hline Acacia senegal & 0.00 & 0.00 & $15.00^{\mathrm{d}}$ & $77.00^{\mathrm{d}}$ & $85.00^{\mathrm{d}}$ & $100^{\mathrm{a}}$ \\
\hline Millettia ferruginea & 0.00 & 0.00 & $10.00^{\mathrm{e}}$ & $85.00^{c}$ & $95.00^{\mathrm{b}}$ & $100^{\mathrm{a}}$ \\
\hline Vernonia amygadalina & 0.00 & 0.00 & $20.00^{c}$ & $90.00^{\mathrm{b}}$ & $90.00^{c}$ & $100^{\mathrm{a}}$ \\
\hline$P B S$ & 0.00 & 0.00 & $0.00^{f}$ & $0.00^{\mathrm{f}}$ & $0.00^{f}$ & $1.00^{c}$ \\
\hline Levamisole $(0.5 \mathrm{mg} / \mathrm{ml})$ & 0.00 & $20^{\mathrm{a}}$ & $50^{\mathrm{a}}$ & $100^{\mathrm{a}}$ & $100^{\mathrm{a}}$ & $100^{\mathrm{a}}$ \\
\hline SEM & 0.00 & 0.22 & 0.54 & 0.51 & 0.51 & 0.42 \\
\hline
\end{tabular}

\section{Discussion}

Overall, the extracts of the five tropical plants, which were examined in the current study, had in vitro effects on the different $H$. contortus life-cycle stages. Recent in vivo studies in goats suggest that the consequences of consumption of tannin-containing plants on the biology of worm populations could differ depending on the parasitic stage present in the host (Paolini et al., 2003a, b).

The results obtained from EHA indicated that the five plant extracts have in vitro ovicidal activity. Concentration-dependent effects on egg hatching were found with the extracts of the five plants. The plant extracts induced inhibition of egg hatching from 17 to $50 \%$ at the concentration of 75 to $1200 \mu \mathrm{g} / \mathrm{ml}$. These results are comparable to the findings of Bogning et al. (2016) who reported a range of egg hatching inhibition rates from 22 to $51 \%$ with leaf extracts of Crassocaphalum crepidioides at a concentration of 75 to $2400 \mu \mathrm{g} / \mathrm{ml}$. Similar results were reported on $H$. contortus eggs by Hounzangbe-Adote et al. (2005) with extracts from four plants of South of Benin (Morinda lucida, Carica papaya, Newbouldia laevis, and Zanthoxylum zanthoxylö̈des) where the inhibition rates ranged between 40 and $60 \%$. In general, the extracts of the 5 browses in the current study had ovicidal activity. However, the reductions observed remained relatively limited, since maximal reductions in egg hatching were around $50 \%$. 
The effects of plant extracts on the third-stage larvae were not concentrationdependent. However, the migration inhibition rate of four out of five plant extracts ranged from 57 to $70 \%$ at the concentration of $300 \mu \mathrm{g} / \mathrm{ml}$. These results were comparable to the findings of Hounzangbe-Adote et al. (2005) who reported a range of larval migration inhibition rates from 50 to $75 \%$ with extracts of tropical plants of South of Benin at a concentration of $300 \mu \mathrm{g} / \mathrm{ml}$. Molan et al. (2000a) found a $80 \%$ inhibition of migration for H. contortus with Hedysarum coronarium extract at a concentration of $1000 \mu \mathrm{g} / \mathrm{ml}$. Alonso-Diaz et al. (2008a, b) tested Acacia pennatula and A. gaumeri extracts and found an inhibition rate of $51 \%$ at $1200 \mathrm{mg} / \mathrm{ml}$ and $93.5 \%$ at $600 \mathrm{mg} / \mathrm{ml}$. The $10 \%$ inhibition effect observed in the negative control (PBS) could be due to the natural phenomena.

The adult worm mortality rate caused by plant extracts ranged from 17 to $90 \%$ and 50 to $95 \%$ at 4 and $6 \mathrm{~h}$ post-incubation, respectively. Moreover, all extracts except extract of Acacia seyal induced $100 \%$ adult mortality at $8 \mathrm{~h}$ post-incubation. These results are comparable with the findings of Singh et al. (2016) who reported a mortality rate of 64 and $100 \%$ for adult $H$. contortus at 6 and $8 \mathrm{~h}$ post-incubation, respectively, with aqueous extract of Zanthoxylum armatum $(100 \mathrm{mg} / \mathrm{ml})$. Tariq et al. (2009) reported an adult worm mortality rate of 55 and $85 \%$ at 4 and $8 \mathrm{~h}$ post-incubation with ethanolic extracts of Artemisia absinthium with the concentration of $25 \mathrm{mg} / \mathrm{ml}$. Hounzangbe-Adote et al. (2005a) reported the mortality rate of adult $H$. contortus $92 \%$ at $6 \mathrm{~h}$ post-incubation with Newbouldia laevis extract $(2.4 \mathrm{mg} / \mathrm{ml})$.

In the current study, Vernonia amygadalina appeared to be the most active plant against adult worms since the mortality rate was $90 \%$ as soon as $4 \mathrm{~h}$ after incubation. In contrast, Acacia seyal was less efficient under these in vitro conditions.

\section{Conclusions}

All extracts of the five browses inhibited egg hatching in a concentration-dependent manner with a maximum inhibition of $50 \%$ at the highest concentration. All extracts significantly inhibited larval migration compared to the control and the inhibition rate of Vernonia amygadalina was the highest of all other browses at $300 \mu \mathrm{g} / \mathrm{ml}$ concentrations. The highest mortality rates $(90 \%$ and $85 \%$ ) of adult $H$. contortus were induced after $4 \mathrm{~h}$ of incubation by extracts of Vernonia amygadalina and Millettia ferruginea, respectively. Moreover, all 
extracts except Acacia seyal induced 100\% adult mortality at $8 \mathrm{~h}$ post-incubation.

From the results of the current study, it can be concluded that significant inhibition effects were obtained with all five browses on all development stages of $H$. contortus. Particularly, Vernonia amygadalina appeared to be the most active plant against the infective larvae and adult worms since it induced the highest LMI rate at a lower concentration, and highest adult mortality rate as soon as $4 \mathrm{~h}$ after incubation. Hence, the extract from Vernonia amygadalina could be used as a locally available treatment for $H$. contortus infestation for small-scale farmers. But this recommendation should be validated by the invivo experiment, which the current study lacks.

\section{Acknowledgments}

This research project was fully supported by the research fund granted by the Vice President for Research and Technology Transfer of the Hawassa University (HU) for which the authors are highly grateful. The support received from Dr. Berhanu Mekibib, Veterinary Pathology and Parasitology Lab head of HU, in the preparation of all in vitro assays and identification of all three development stages of Haemonchus contortus is highly acknowledged.

\section{References}

Alonso-Díaz, M.A., Torres-Acosta, J.F.J., Sandoval-Castro, C.A., Aguilar-Caballero, A.J and Hoste, H., 2008a. In vitro larval migration and kinetics of exsheathment of Haemonchus contortus exposed to four tropical tanniniferous plants extracts. Vet. Parasitol., 153, 313-319.

Alonso-Díaz, M.A., Torres-Acosta, J.F.J., Sandoval-Castro, C.A., Capetillo- Leal, C., Brunet, S. and Hoste, H., 2008b. Effects of four tropical tanniniferous plants on the inhibition of larval migration and the exsheathment process of Trichostrongylus colubriformis infective stage. Vet. Parasitol., 153, 187-192.

Bogning, Z.C, Olounlade, P.A, Alowanou, G.G, Nguemfo, E.L, Dongmo, A.B, Azebaze, A.G.B. and Hounzangbe, A.S., 2016. In vitro anthelmintic activity of aqueous extract of Crassocephalum crepidioides (Benth.) S. Moore on Haemonchus contortus. J. Exp. Integr. Med., 6(1), 31-37. 
Coles, G.C., Jackson, F., Pomroy, W.E., Prichard, R.K., Samson-Himmelstjerna, von, G., Silvestere, A., et al., 2006. The detection of anthelmintic resistance In nematodes of veterinary importance. Vet. Parasitol., 136, 167-185.

Hammond, G. A., Lyerly, D. M. and Johnson, J. L., 1997. Transcriptional analysis of the toxigenic element of Clostridium difficile. Microb. Pathog., 22, 143-154.

Hoste, H., Brunet, S., Paolini, V., Bahuaud, D., Chauveau, S., Fouraste, I., et al. Compared in vitro anthelmintic effects of eight tannin-rich plants browsed by goats in the southern part of France. In: Papachristou, T.G. (ed.), Parissi, Z.M., (ed.), Ben Salem, H. (ed.), Morand-Fehr, P. (ed.). Nutritional and foraging ecology of sheep and goats. Zaragoza: CIHEAM / FAO / NAGREF, 2009. p. 431- 436 (Options Méditerranéennes : Série A. Séminaires Méditerranéens; n. 85).

Hounzangbe-Adote, M.S., Paolini, V., Fouraste, I., Moutairou, K. and Hoste, H., 2005. In vitro effects of four tropical plants on three life-cycle stages of the parasitic nematode, Haemonchus contortus. Res. Vet. Sci., 78,155-160.

Makkar, H.P.S. 2003a. Quantification of Tannins in Tree and Shrub Foliage. A Laboratory Manual. Joint FAO/IAEA, Division of Nuclear Techniques in Food and Agriculture. Kluwer Academic Publishers, Dordrecht, the Netherlands.

Molan, A.L., Waghorn, G.C., Min and, B.R. and McNab, W.C. 2000a. The effect of condensed tannins from seven herbages on Trichostrongylus colubriformis larval migration in vitro. Folia Parasitol., 47, 39-44.

Molan, A.L., Hoskin, S.O., Barry, T.N. and McNab, W.C., 2000b. The effect of condensed tannins extracted from four forages on deer lungworm and gastrointestinal nematode viability. Vet. Rec., 147, 44-81.

Niezen, J.H., Hodgson, J., Charleston, W.A.G. and Waghorn, T.S., 1993. Effect of four grass species on lamb parasitism and growth. Proc. N. Z. Grassland Assoc., 55, 203-206.

Nginyi, J.M., Duncan, J.L., Mellor, D.J., Stear, M.J., Wanyangu, S.W., Bain and, R.K., Gatongi, P.M., 2001. Epidemiology of parasitic gastrointestinal nematode infections of ruminants on smallholder farms in central Kenya. Res. Vet. Sci., 70, 33-43.

Paolini, V., Bergeaud, J.P., Grisez, C., Prevot, F., Dorchies, P. and Hoste, H., 2003a. Effects of condensed tannins on goats experimentally infected with Haemonchus contortus. Vet. Parasitol., 113, 253-261.

Paolini, V., Frayssines, A., De La Farge, F., Dorchies, P. and Hoste, H., 2003b. Effects of condensed tannins on established populations and incoming larvae of Trichostrongylus colubriformis and Teladorsagia circumcincta in goats. Vet. Res., 4, 331-339.

Papachristou, T.G., Dziba, L.E. and Provenza, F.D., 2005. Foraging ecology of goats and sheep on wooded rangeland. Small Rumin. Res., 59, 141-156.

Ethiop. Vet. J., 2021, 25 (2), 132-143 
Pathak, A. K., 2011. Nutritional status and performance of ruminants as influenced by gastrointestinal nematodes - an overview. NEV, 11(3), 20-26.

Pathak, A. K., 2013. Potential of using condensed tannins to control gastrointestinal nematodes and improve small ruminant performance. Int. J. Mol. Vet. Res., 3(8), 36-50.

Qamar, M. and Maqbool, A., 2012. Biochemical studies and serodiagnosis of haemonchosis in sheep and goats. J. Anim. Plant Sci., 22(1), 32-38.

Rabel, B., Mcgregor, R. and Douch, P.G.C., 1994. Improved bioassay for estimation of inhibitory effects of ovine gastrointestinal mucus and anthelmintics on nematode larval migration. Int. J. Parasitol., 24, 671-676.

Singh, G. R., Singh, P.K., Verma, R. and Singh, A., 2016. Anthelmintic efficacy of aqueous extract of Zanthoxylum armatum DC. seeds against Haemonchus contortus of small ruminants. J. Parasit. Dis., 40(2),528-532.

Tariq, K.A., Chishti, M.Z., Ahmad, F. and Shawl, A.S. 2009. Anthelmintic activity of extracts of Artemisia absinthium against ovine nematodes. Vet. Parasitol.,160, 83-88. 